\title{
Wstępne wyniki analizy petrograficznej osadów w żwirowni Łubienica-Superunki
}

\author{
Preliminary results of petrographic analysis of deposits in Łubienica-Superunki gravel pit
}

\section{Maria Górska-Zabielska}

Uniwersytet Jana Kochanowskiego, Instytut Geografii, Kielce; maria.gorska-zabielska@ujk.edu.pl

\begin{abstract}
Zarys treści: Osady piaszczysto-żwirowe pochodzace $z$ transgresji stadiału młodszego zlodowacenia warty w ŁubienicySuperunkach zostały zbadane pod kątem składu petrograficznego frakcji średniożwirowej i grubożwirowej. Stwierdzono wyraźna przewage skał krystalicznych, brak skał weglanowych oraz dziesieccioprocentowy udział piaskowców. Kwarc zmniejsza swój udział z około $9 \%$ we frakcji średniożwirowej do 0,6\% we frakcji grubożwirowej. We frakcji 20-60 mm zidentyfikowano narzutniaki fennoskandzkie. Wśród nich były narzutniaki przewodnie z Wysp Alandzkich i sąsiadujących regionów Uppland i dna północnego Bałtyku oraz z obszaru południowo-wschodniej Szwecji (Småland). Wśród narzutniaków wskaźnikowych nie znaleziono ani jednego egzemplarza skały węglanowej.
\end{abstract}

Słowa kluczowe: analiza petrograficzna żwirów, narzutniaki fennoskandzkie, zlodowacenie warty, Nizina Północnomazowiecka

Abstract: Sandy and gravel deposits, originating from the ice sheet transgression during the younger stadial of the Warthanian glaciation in Łubienica-Superunki, have been examined in terms of petrographic composition of the middle-coarse gravel fraction and pebble fraction. The distinct predomination of crystalline rocks, no carbonate rocks and a $10 \%$ share of sandstones have been ascertained. Quartz has reduced its share from about $9 \%$ in the middle-coarse gravel fraction to $0.6 \%$ in pebble fraction. The Scandinavian erratics have been identified within the $20-60 \mathrm{~mm}$ fraction. Among them the indicator erratics from the Åland Islands, neighboring Uppland, North Baltic bottom and Småland have been found. There was no single carbonate rock found among the so called statistical erratics.

Keywords: petrographic analysis of gravels, Scandinavian erratics, Warthanian glaciation, North-Masovian Lowland

\section{Wstęp}

Stanowisko w Łubienicy-Superunkach leży w obrębie płaskiej wysoczyzny polodowcowej, na pograniczu Doliny Dolnej Narwi i Wysoczyzny Ciechanowskiej Niziny Północnomazowieckiej (Kondracki 2000). Odsłaniające się w nim osady piaszczyste to, zdaniem Nowak (1969), utwory pokrywowe powstałe w czasie zlodowacenia wisły ze zwietrzenia i rozmycia gliny lodowcowej i piasków lodowcowych zakumulowanych wcześniej, prawdopodobnie podczas fazy wierzbickiej stadiału północnomazowieckiego.
W świetle nowszych badań jest to odpowiednik stadiału środkowego zlodowacenia warty (Kucharska, Pochocka-Szwarc 2012) względnie stadiału warty zlodowacenia środkowopolskiego (Marks i in. 2016). Według Frankiewicza (2017) wybrane do analizy żwiry pochodzą $\mathrm{z}$ transgresji młodszego stadiału zlodowacenia warty. W okresie, kiedy wykonywano badania na potrzeby SMGP (ark. Serock, nr 0450), złoże w Łubienicy-Superunkach nie było znane ani tym bardziej eksploatowane. Stąd w opracowaniu Nowak (1969) nie ma informacji na temat przeprowadzonych analiz petrograficznych osadów piaszczy- 
sto-żwirowych na badanym stanowisku. W jej pracy są jedynie zawarte wyniki bardzo ograniczonych badań (wyróżniono zaledwie trzy typy petrograficzne), jakimi objęto glinę lodowcową odsłaniającą się w strefie glacjomarginalnej fazy wierzbickiej stadiału północnomazowieckiego zlodowacenia środkowopolskiego, w odległości około $6 \mathrm{~km}$ na południe od Łubienicy-Superunek.

W związku z powyższym należy przyjąć, że osady występujące $w$ żwirowni Łubienica-Superunki nie były jak dotąd $\mathrm{w}$ ogóle przebadane pod kątem składu petrograficznego, $\mathrm{w}$ tym nie przeprowadzono identyfikacji fennoskandzkich eratyków przewodnich. Głównym celem podjętych badań jest zatem poznanie spektrum petrograficznego osadów średniożwirowych i grubożwirowych zlodowacenia środkowopolskiego, występujących $\mathrm{w}$ badanym stanowisku. Celem badań jest także próba korelacji badanych osadów z osadami pogranicza Doliny Dolnej Narwi i Wysoczyzny Ciechanowskiej, występującymi w granicach sąsiednich arkuszy SMGP. Z wynikami analiz petrograficznych frakcji grubożwirowej autorka wiąże nadzieję na wskazanie obszaru alimentacyjnego tej części lądolodu, której masy lodu dotarły po obszar badań.

Przeprowadzenie badań nad składem petrograficznym w osadach glacjofluwialnych wpisuje się w nurt badań autorki (Górska 2000a, 2002, 2003, 2006, Górska-Zabielska 2008, Górska-Zabielska,
Wachecka-Kotkowska 2014, 2015 i tamże przegląd literatury), skupiających się wokół zagadnienia przydatności tego typu litogenetycznego osadów w analizach zmierzających do interpretacji proweniencji lądolodu.

Pobrane w spągu południowej ściany czynnej żwirowni Łubienica-Superunki osady zostały przeanalizowane pod kątem składu petrograficznego frakcji średniożwirowej (4-10 mm) i grubożwirowej (20-60 $\mathrm{mm})$. Ponadto w osadach grubszych zidentyfikowano fennoskandzkie eratyki przewodnie. Prace terenowe $i$ analizy laboratoryjne wykonano zgodnie $z$ zasadami metodycznymi wielu autorów, podanymi w publikacjach autorki (m.in. Górska 2000b, 2003, Górska-Zabielska 2008).

\section{Zakres badań}

Południową ścianę odsłonięcia (nr 1 na ryc. 1) w żwirowni Łubienica-Superunki, o wysokości około $10 \mathrm{~m}$, tworzy (stan na czerwiec $2017 \mathrm{r}$.) w całości osad piaszczysty warstwowany horyzontalnie Sh oraz warstwowany przekątnie płasko Sp, z rzadkimi soczewkami osadów średniożwirowych Gh, Gp. Frakcja żwirów gruboziarnistych występuje bardzo sporadycznie. Na głębokości około 8-9 m poniżej współczesnej rzędnej terenu pobrano dwie próbki

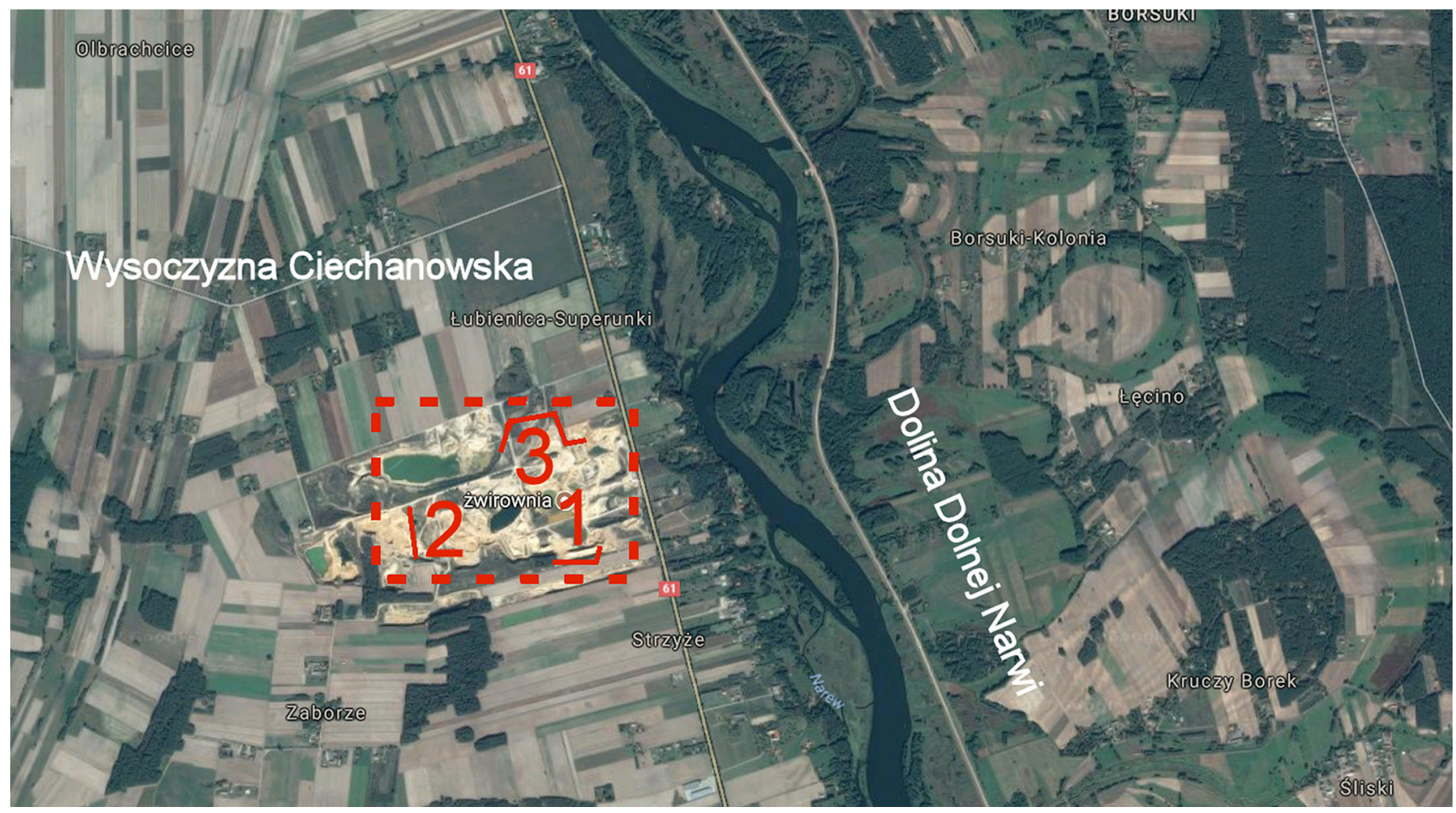

Ryc. 1. Lokalizacja południowej ściany (1) w żwirowni w Łubienicy-Superunkach na tle SMGP, ark Serock (Nowak 1969, zmienione; zdjęcie satelitarne z Google Maps)

Fig. 1. Location of the southern wall (1) in Łubienica-Superunki gravel pit against the Detailed geologicial map of Poland, sheet Serock (Nowak 1969, changed; satellite image by Google maps) 


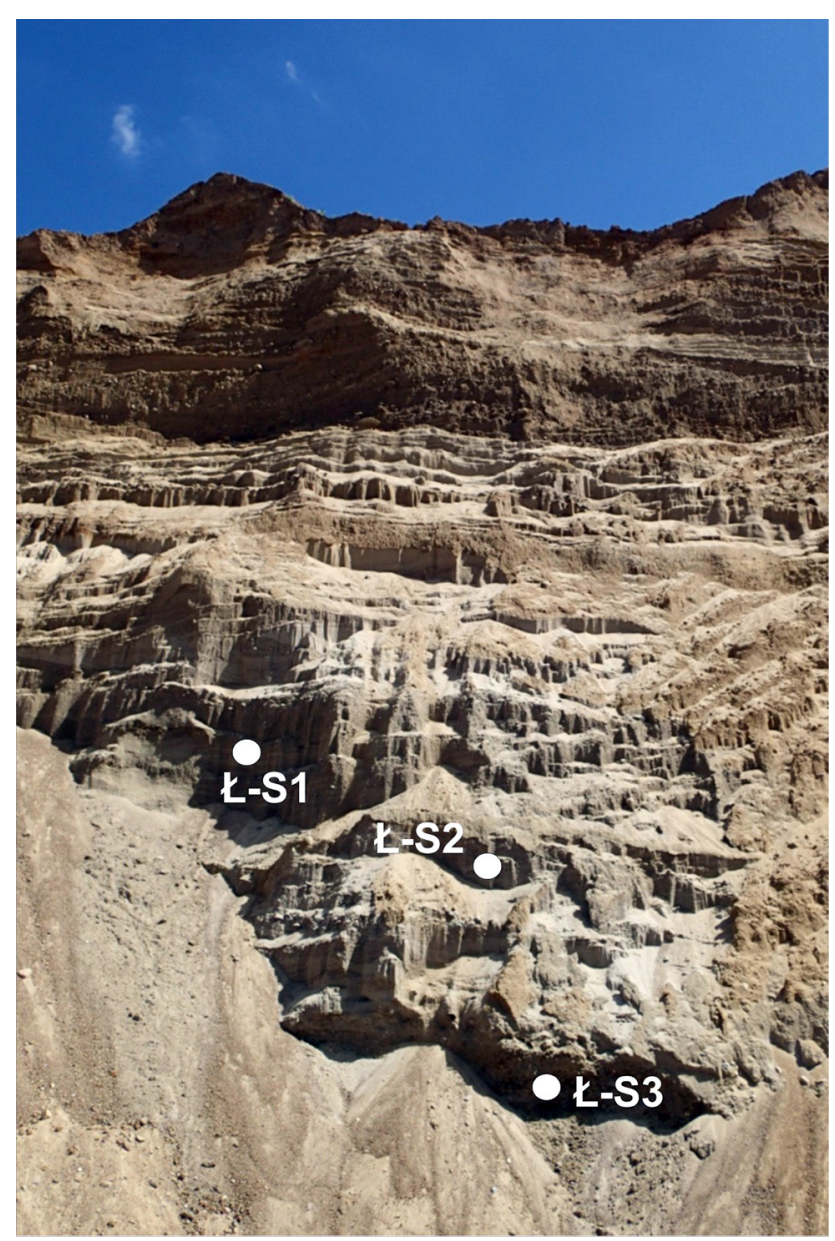

Ryc. 2. Lokalizacja miejsc poboru próbek Ł-S1, Ł-S2, Ł-S3 w południowej ścianie żwirowni w Łubienicy-Superunkach (fot. E. Smolska 2017)

Fig. 2. Location of samples Ł-S1, Ł-S2, Ł-S3 in Łubienica-Superunki gravel pit (photo: E. Smolska 2017)

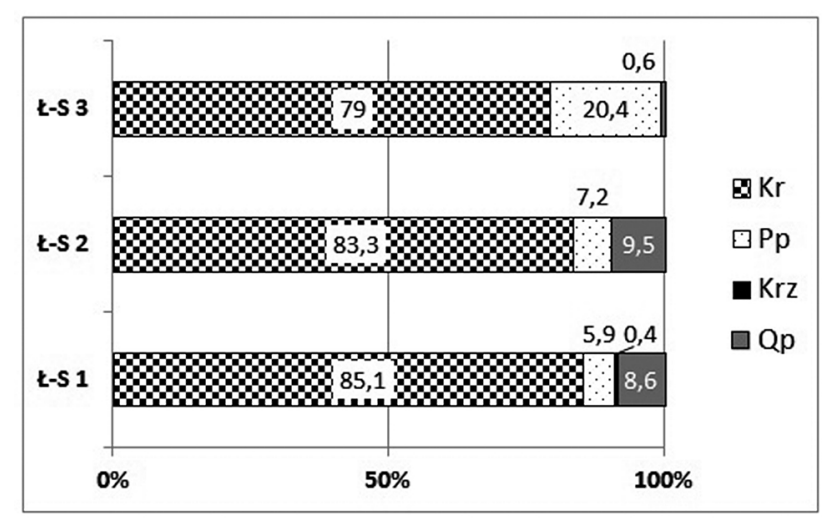

Ryc. 3. Skład petrograficzny frakcji średniożwirowej (próbki Ł-S1 i Ł-S2) oraz grubożwirowej (próbka Ł-S3)

$\mathrm{Kr}$ - skały krystaliczne, Pp - piaskowce, Krz - krzemienie, Qp - kwarc

Fig. 3. Petrographic composition of gravels of the $4-10 \mathrm{~mm}$ (samples Ł-S1 and Ł-S2) and gravels of the $20-60 \mathrm{~mm}$ (E-S3)

$\mathrm{Kr}$ - crystallines, $\mathrm{Pp}$ - sandstones, $\mathrm{Krz}$ - flints, Qp - quartz osadów średniożwirowych (Ł-S1 i Ł-S2) oraz jedną próbkę osadów grubożwirowych (Ł-S3; ryc. 2).

W toku prac laboratoryjnych, uwzględniając zalecenia metodyczne Trembaczowskiego (1961, 1967) i Böse (1989), dotyczące statystycznie reprezentatywnej liczby ziaren, oraz Rutkowskiego (1995), związane z kwartowaniem próbki, zakwalifikowano do analizy petrograficznej po 310 i 293 szt. ziaren próbek frakcji 4-10 mm, odpowiednio S-Ł1 i S-Ł2. Mając na uwadze zalecenia Lüttiga (1958) i Meyera (1983, 1985), do analizy narzutniaków fennoskandzkich zakwalifikowano 521 okazów skał frakcji 20-60 mm (S-Ł3).

\section{Wyniki}

\section{Skład petrograficzny frakcji średniożwirowej i grubożwirowej osadów glacjofluwialnych}

W obu próbkach osadów frakcji średniożwirowej (ŁS1 i Ł-S2; ryc. 3) zanotowano podobny skład petrograficzny: zdecydowanie dominują skały krystaliczne (Kr 83,3-85,1\%). Kwarc Qp jest obecny w około 9\%; piaskowców - niewiele mniej (Pp 5,9-7,2\%). W jednej próbce zidentyfikowano 1 okaz krzemienia Krz. W badanych osadach nie stwierdzono obecności skał węglanowych.

W próbce frakcji grubożwirowej (próbka Ł-S3; frakcja 20-60 mm) występują praktycznie wyłącznie skały krystaliczne $(79 \%)$ i piaskowce $(20,4 \%)$. Kwarc występuje w śladowych ilościach, tj. 0,6\%. Podobnie, jak we frakcji drobniejszej, także i tu nie odnotowano obecności skał węglanowych.

\section{Eratyki przewodnie}

Wśród dominujących w próbce żwirów gruboziarnistych (20-60 mm) skał krystalicznych (79\%) stwierdzono obecność sześciu typów eratyków przewodnich. Najwięcej okazów pochodzi z rejonu Wysp Alandzkich; są to alandzkie porfiry kwarcowe (26 szt.; ryc. 4). Drugą grupą eratyków są granity z południowo-wschodniej Szwecji, z regionu Småland (18 szt.). Z tego samego obszaru macierzystego pochodzi 5 egz. kwarcowych porfirów Småland. Z dna Bałtyku, $z$ okolic na południe od Wysp Alandzkich, pochodzą 4 okazy czerwonego porfiru bałtyckiego. W próbce stwierdzono ponadto obecność 3 granitów Uppsala (z regionu Uppland) i 2 - porfirów Bredvad (z regionu Dalarna; ryc. 4, 5).

W grupie skał osadowych zidentyfikowano eratyki wskaźnikowe, tj. 28 piaskowców jotnickich (o wychodniach $\mathrm{w}$ dnie środkowego i północnego Bałtyku oraz z Dalarny) i 1 egzemplarz piaskowca, przypuszczalnie kredowego ( $\mathrm{z}$ dna południowego Bałtyku; ryc. 5). 


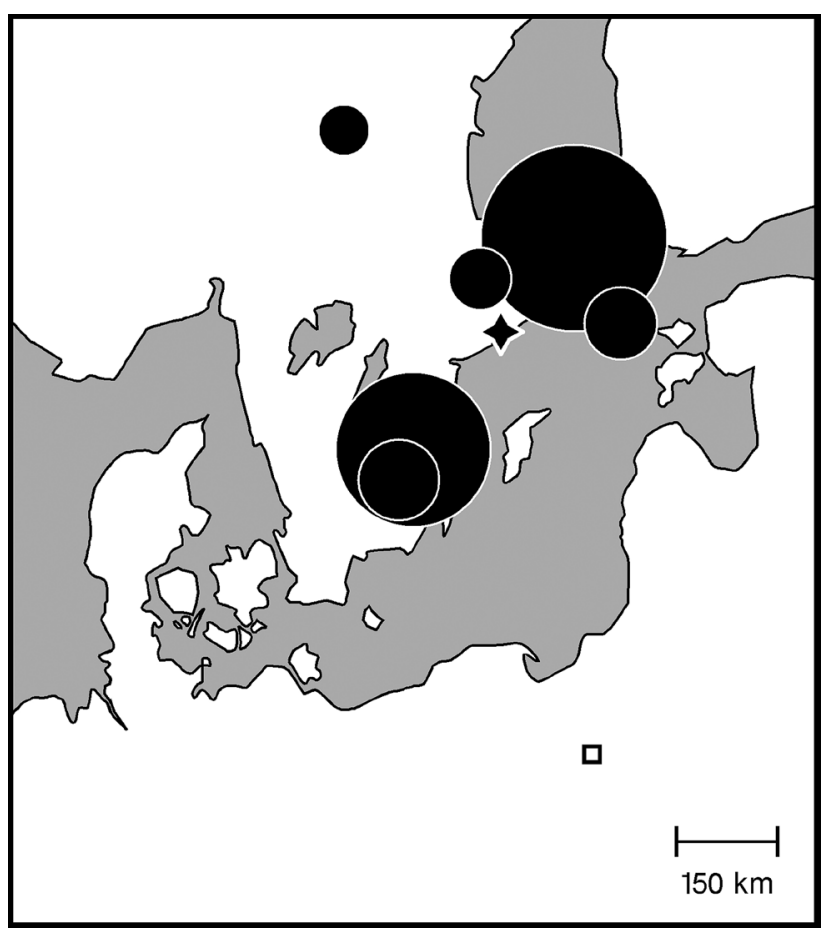

Ryc. 4. Pochodzenie eratyków przewodnich, zidentyfikowanych w osadach grubożwirowych żwirowni Łubienica Superunki.

Średnica kół jest uzależniona od liczebności rodzajów eratyków przewodnich. Białym kwadratem zaznaczono lokalizację żwirowni. Gwiazdką zaznaczono lokalizację teoretycznego centrum głazowego TCG

Fig. 4. The origin of the indicator erratics identified in 20$60 \mathrm{~mm}$ gravels in the Łubienica - Superunki gravel pit.

The diameter of the circles depends on the number of the indicator erratics. White box stands for the study site. Star symbol stands for the theoretical stone center TSC

Wyliczone na podstawie eratyków przewodnich (nr 1-5 na ryc. 5) teoretyczne centrum głazowe TCG (Lüttig 1958) badanych osadów zlokalizowane jest w punkcie o współrzędnych $59^{\circ} \mathrm{N}$ i $18^{\circ} \mathrm{E}$.

\section{Dyskusja}

Mając na uwadze doświadczenia i uzyskane wyniki badań petrograficznych żwirów gliny lodowcowej i odpowiadających jej chronostratygraficznie osadów fluwioglacjalnych w różnych częściach Polski oraz w NE Niemczech (Górska 2000a, 2002, 2003, 2006, Górska-Zabielska 2008, Górska-Zabielska, Wachecka-Kotkowska 2014, 2015), zdecydowano się podjąć takie badania także na północnym Mazowszu, obszarze jak dotąd nieznanym autorce.

Podejmując próbę korelacji otrzymanych wyników wstępnych badań petrograficznych osadów żwirowni Łubienica-Superunki, należy przywołać tu wyniki mało szczegółowej analizy petrograficz-
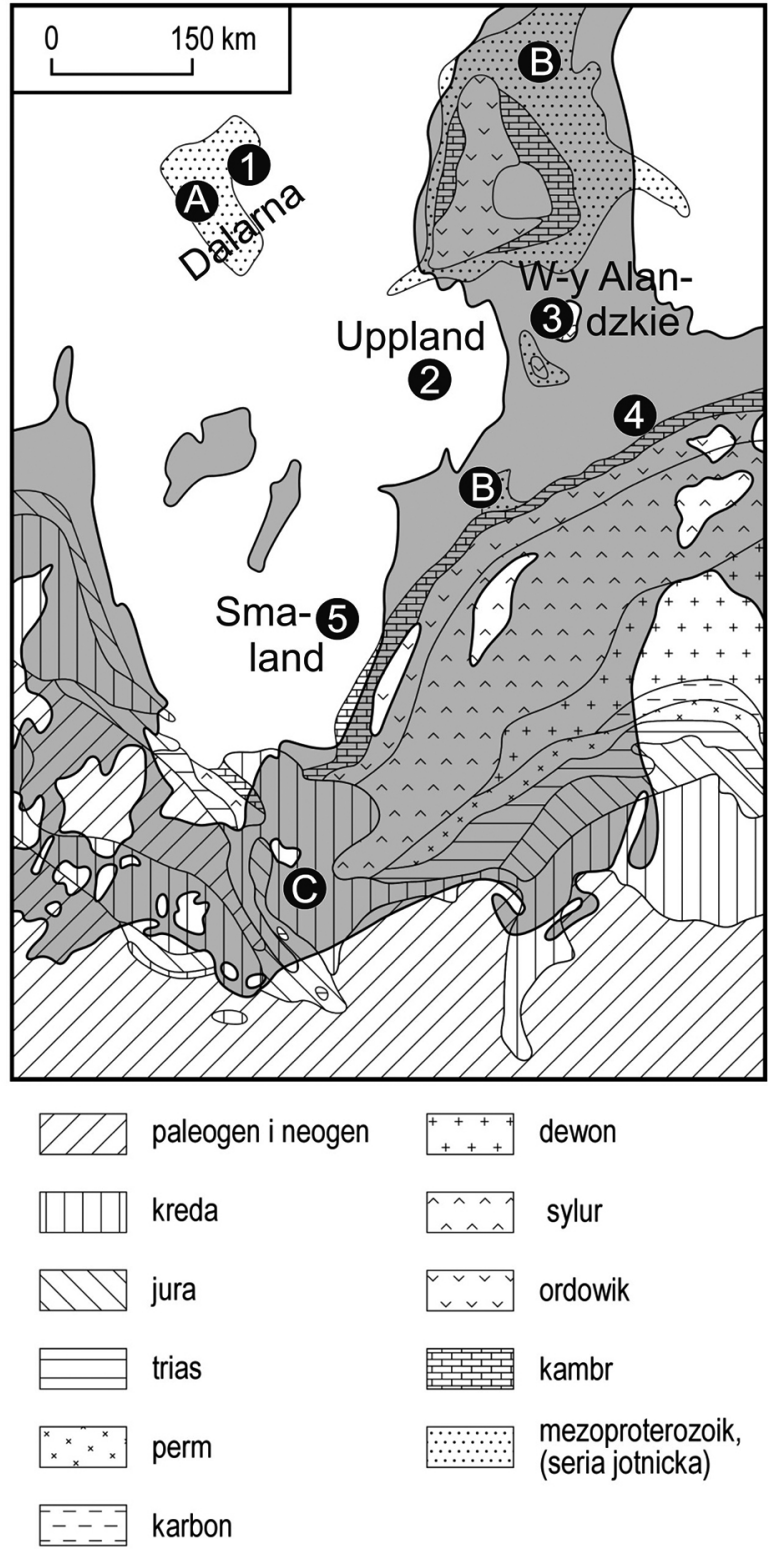

Ryc. 5. Lokalizacja wychodni zidentyfikowanych w osadach żwirowni Łubienica-Superunki eratyków przewodnich i symboliczna lokalizacja wychodni eratyków wskaźnikowych na tle zasięgu występowania fennoskandzkich obszarów źródłowych.

W żwirowni Łubienica-Superunki zidentyfikowano eratyki przewodnie: 1 - porfir Bredvad, 2 - granit Uppsala, 3 - porfir kwarcowy Åland, 4 - czerwony porfir bałtycki, 5 - granit Småland i eratyki wskaźnikowe: A - piaskowiec Dalarna, B - piaskowiec jotnicki, C - piaskowiec kredowy

Fig. 5. Location of the outcrops of, identified in the Łubienica-Superunki gravel pit, indicator erratics and symbolic location of the outcrops of so called statistical erratics, against the limits of Fennoscandian source areas.

In the Łubienica-Superunki gravel pit the following indicator erratics were identified: 1 - Bredvad porphyry, 2 - Uppsala granite, 3 - Åland quartz porphyry, 4 - red Baltic porphyry, 5 - Småland granite as well as so called statistical erratics: A - Dalarna sandstone, B - Jotnian sandstone, C - Cretaceous sandstone 
Tabela 1. Skład petrograficzny piasków i żwirów w Dzierżeninie dla ziarn powyżej 2 mm, w \% (Nowak 1969: 27) Table 1. Petrographic composition of sands and gravels in Dzierżenin, fraction bigger than 2 mm, in \% (Nowak 1969: 27)

\begin{tabular}{lcccc}
\hline \multirow{2}{*}{ Skład petrograficzny } & \multicolumn{2}{c}{ Część południowa } & \multicolumn{2}{c}{ Część północna } \\
\cline { 2 - 5 } & $1,7-1,3$ & $2,0-4,9$ & $0,2-1,9$ & $1,9-4,3$ \\
\hline Skał magnetycznych i metamorficznych & 50 & 40 & 50 & 70 \\
Wapieni & 48 & 55 & 45 & 22 \\
Kwarcytów & 2 & 5 & 5 & 8 \\
\hline
\end{tabular}

nej przeprowadzonej w Dzierżeninie, gdzie zbadano glinę lodowcową strefy glaciomarginalnej fazy wierzbickiej stadiału północnomazowieckiego zlodowacenia środkowopolskiego (Balzam 1958, por. Nowak 1969; tab. 1). W składzie petrograficznym osadów piaszczystych frakcji powyżej $2 \mathrm{~mm}$ zidentyfikowano 40-70\% skał magnetycznych (prawdopodobnie Balzam (1958) miał na myśli skały magmowe) i metamorficznych, $22-55 \%$ wapieni oraz 2-8\% kwarcytów. Autor w badanych próbkach nie stwierdził obecności piaskowców ani ziaren kwarcu. Stwierdził natomiast dużą zawartość wapieni, których udział procentowy zbliżony jest do skał magmowych i metamorficznych.

Powyższe wyniki są nieporównywalne $z$ wynikami uzyskanymi przez autorkę, bo wydzielane grupy petrograficzne są różne. Można je traktować tylko w kategoriach poglądowych. $\mathrm{Z}$ tego samego powodu nie można porównać składu petrograficznego żwirów z Łubienicy-Superunek z równowiekowymi osadami występującymi w granicach arkusza SMGP Nasielsk (nr 449), sąsiadującego od zachodu. Trwające prace reambulacyjne arkuszy SMGP Nasielsk i Serock (nr 450) wniosą nowe dane, zwłaszcza wyniki standardowych analiz petrograficznych osadów glacigenicznych, które posłużą do korelacji z wynikami uzyskanymi w żwirowni Łubienica-Superunki.

Wyniki analiz petrograficznych omawianych w tym artykule żwirów średnioziarnistych można porównać $z$ wynikami analiz zrealizowanych $\mathrm{w}$ ramach SMGP ark. Wyszków (nr 451; Kucharska, Pochocka-Szwarc, 2012), ponieważ charakteryzują się podobną metodyką. Podnoszone wątpliwości związane $\mathrm{z}$ analizowanymi innymi przedziałami frakcjonalnymi żwirów średnich $(4 / 5-10 \mathrm{~mm})$ zostały szczegółowo wyjaśnione przez Lipkę (2012).

Zabielski (2006) podaje, że skład petrograficzny frakcji średniożwirowej najmłodszego poziomu glin lodowcowych (SMGP, ark. Wyszków) charakteryzuje się przewagą skał węglanowych nad skałami krystalicznymi. Gliny o podobnych cechach składu petrograficznego i tym samym o porównywalnych wartościach wskaźników petrograficznych, zdaniem tego autora, występują w profilach kartograficznych odwierconych na terenie sąsiednich arkuszy SMGP: Kamieńczyk, Sadowne, Jadów (Komacka-Makowiecka 1998, 1999, 2000, por. Zabielski 2006), Liw (Gonczaruk 1998, por. Zabielski 2006) oraz Mińsk Mazowiecki i Kałuszyn (Kenig 1999, 2001, por. Zabielski 2006), gdzie kore- lowane są ze zlodowaceniem warty. Glinę lodowcową w Dzierżeninie (ark. Serock), zbadaną petrograficznie, co prawda w wąskim zakresie, cechuje jednakże niewiele różniący się skład petrograficzny (tab. 1).

Zbadane $\mathrm{w}$ Łubienicy-Superunki żwiry zarówno frakcji średnio-, jak i grubożwirowej są całkowicie pozbawione skał węglanowych. Natomiast przeważają w nich skały krystaliczne. Dominacja odpornych skał krystalicznych może wskazywać, że badany osad w Łubienicy-Superunkach ma zmieniony pierwotny skład petrograficzny. Dużo mniej jest piaskowców i ziaren kwarcu. Przy czym żwir kwarcowy obecny jest przede wszystkim we frakcji średniożwirowej. Jego liczebność spada poniżej $1 \%$ we frakcji grubożwirowej, co jest cechą typową osadów o większej średnicy ziarna (np. Schulz 1996, Górska 2000b).

Eratyki przewodnie stanowią 10,1\% wszystkich skał badanej próbki frakcji 20-60 mm, co, zgodnie z sugestiami Meyera (1983, 1985), jest wielkością wystarczającą, by na tej podstawie wskazać źródła alimentacji lądolodu transportującego osady na obszar Mazowsza. Tor wędrówki lądolodu środkowopolskiego, zanim dotarł on na Mazowsze, przebiegał po wychodniach skał krystalicznych środkowej i południowo-wschodniej Szwecji oraz północnego Bałtyku. Brak skał węglanowych, pochodzących $z$ dna środkowego Bałtyku, można tłumaczyć trojako. Spływające po obszar badań na Mazowszu masy lodu po prostu ominęly ten teren alimentacyjny, bo były np. zasilane $\mathrm{z}$ centrum zlodowacenia, zlokalizowanego w części środkowej Półwyspu Skandynawskiego. O zmianach trajektorii mas lodowcowych jako efekcie przemieszczania się centrów zlodowaceń pisali ostatnio Marks i in. (2016). Na tę kwestię zwracał uwagę wcześniej m.in. Ehlers (1990). Być może egzaracja skał węglanowych środkowego Bałtyku była niemożliwa/utrudniona $z$ uwagi na zaleganie na nich zimnego lądolodu, którego stopa była trwale przymarznięta do podłoża. I w końcu nie można wykluczyć zubożenia materiału eratycznego wskutek zwietrzenia. Podczas gdy efektem dwóch pierwszych przyczyn jest całkowita nieobecność skał takich obszarów źródłowych, efektem zwietrzenia jest najczęściej ubytek jedynie pewnej (mniejszej lub większej) części, a nie całkowity brak skał z danego obszaru macierzystego. W żadnej $z$ badanych próbek żwiru z Łubienicy-Superunek nie znaleziono ani jednego okazu skały węglanowej. 
Matematycznie wyliczone teoretyczne centrum głazowe TCG dla próbki żwirów gruboziarnistych $\mathrm{w}$ Łubienicy-Superunkach lokuje się $\mathrm{W}$ punkcie o współrzędnych $59^{\circ} \mathrm{N}$ i $18^{\circ}$ E. Porównując tę wartość z TCG powierzchniowych osadów glacjalnych zlodowacenia warty z lobów Widawki oraz Pilicy i Luciąży, na pograniczu niżu i wyżyn Polski (Górska-Zabielska, Wachecka-Kotkowska 2014, 2015: 16,4-17,0E oraz $\left.57,5-58,7^{\circ} \mathrm{N}\right)$, można stwierdzić, że istniejąca różnica $\mathrm{w}$ lokalizacji tych punktów wynika $\mathrm{z}$ innych wartości współrzędnych geograficznych badanych stanowisk. Ta część lądolodu warciańskiego, która zdeponowała swój ładunek skalny na obszarze północnego Mazowsza, miała większe możliwości egzaracyjne na obszarach źródłowych granitów alandzkich i granitów Småland. Natomiast część lądolodu, która dotarła aż po strefę glacjomarginalną w środkowej Polsce, rozwinęła swe zdolności egzaracyjne na obszarze dzisiejszej południowowschodniej Szwecji oraz zachodniej części środkowego Bałtyku.

\section{Podsumowanie}

Badania petrograficzne $\mathrm{w}$ osadach pochodzących z rozmycia gliny i piasków zwałowych, występujących w żwirowni Łubienica-Superunki, mają charakter pilotażowy. Niemniej dają już pewien pogląd na skład petrograficzny tych osadów.

Można stwierdzić, że powierzchniowe osady piaszczysto-żwirowe pogranicza Doliny Dolnej Narwi i Wysoczyzny Ciechanowskiej są odwapnione, składają się głównie $z$ odpornych na zniszczenie skał krystalicznych. Badania petrograficzne gliny lodowcowej (w ramach SMGP) tego regionu wskazują na przewagę skał węglanowych nad krystalicznymi. Niecałe $10 \%$ składu petrograficznego, niezależnie od frakcji, stanowią piaskowce. Ziarna kwarcu zmniejszają swój procentowy udział z około $9 \%$ we frakcji średniożwirowej do $0,6 \%$ we frakcji grubożwirowej.

W zespole narzutniaków zidentyfikowano przede wszystkim skały pochodzące z rejonu Wysp Alandzkich i sąsiadujących regionów Uppland i dna Bałtyku północnego oraz z obszaru południowo-wschodniej Szwecji (Småland). Wśród narzutniaków wskaźnikowych nie znaleziono ani jednego egzemplarza skały węglanowej.

Całkowity brak skał węglanowych w obu badanych frakcjach żwirów może wskazywać na obecność części lądolodu o zimnej stopie, przytwierdzonej do podłoża w miejscu wychodni dolnopaleozoicznych i dewońskich, na nieprzemieszczanie się lądolodu po tych wychodniach i w końcu na eliminację rozpuszczalnych skał węglanowych. Takie postsedymentacyjne zwietrzenie mogło zostać pogłębione wskutek zwietrzenia skał magmowych i metamorficznych, zawierających dużo minerałów mało odpornych na wietrzenie chemiczne. Jak dotąd nie ma przesłanek, by wykluczyć którąś $z$ tych hipotez.

Zaprezentowane wyniki bardzo wstępnych badań petrograficznych osadów piaszczysto-żwirowych $\mathrm{w}$ Łubienicy-Superunkach muszą być poszerzone o reprezentatywną liczbę próbek osadów frakcji średnio- i grubożwirowej osadów depozycji glacjalnej i glacjofluwialnej Niziny Północnomazowieckiej, pochodzących $z$ tego samego nasunięcia lądolodu. Dopiero na tej podstawie będzie można odpowiedzieć na postawione w tym artykule pytania i rozwiać wątpliwości.

\section{Literatura}

Böse M., 1989. Methodisch-stratigraphische Studien und paläomorphologische Untersuchungen zum Pleistozän südlich der Ostsee. Berliner Geographische Abhandlungen 51: 114.

Ehlers J., 1990. Reconstructing the dynamics of the North-West European Pleistocene Ice-Sheet. Quaternary Science Review 9: 71-83.

Frankiewicz A., 2017. Materiały robocze do Szczegółowej mapy geologicznej Polski w skali 1:50 000, arkusz Serock. PIG, Warszawa.

Górska M., 2000a. Narzutniaki skandynawskie - metodyka badań i interpretacja. Analiza eratyków ze stanowiska w Koczerach koło Drohiczyna. W: Warsztaty terenowe „Osady, struktury deformacyjne i formy warciańskiej strefy glacjomarginalnej na Nizinie Podlaskiej". Lublin - Mielnik, 25-29.09.2000: 67-72.

Górska M., 2000b. Wybrane właściwości petrograficzne vistuliańskich moren dennych środkowej i zachodniej Wielkopolski oraz ich znaczenia dla oceny dynamiki ostatniego lądolodu. Poznańskie Towarzystwo Przyjaciół Nauk, Prace Komisji Geograficzno-Geologicznej 28.

Górska M., 2002. Petrografia osadów akumulacji lodowcowej i wodnolodowcowej Pojezierza Drawskiego. Badania Fizjograficzne nad Polską Zachodnią 53(A): 29-42.

Górska M., 2003. Analiza petrograficzna narzutniaków skandynawskich. W: M. Harasimiuk, S. Terpiłowski (red.), Analizy sedymentologiczne osadów glacigenicznych. Wydawnictwo UMCS, Lublin: 23-31.

Górska M., 2006. Narzutniaki przewodnie z Sobolewa (sandr suwalsko-augustowski). Prace Komisji Paleogeografii Czwartorzędu PAU 3: 209-212.

Górska-Zabielska M., 2008. Fennoskandzkie obszary alimentacyjne osadów akumulacji glacjalnej i glacjofluwialnej lobu Odry. Wydawnictwo Naukowe UAM, Geografia 78.

Górska-Zabielska M., Wachecka-Kotkowska L., 2014. Petrographical analysis of Warthian fluvioglacial gravels as a tool to trace the source area - a case study from central Poland. Geologos 20(3): 183-199.

Górska-Zabielska M., Wachecka-Kotkowska L., 2015. Petrografia żwirów i eratyki przewodnie w osadach wodnolodowcowych jako przesłanki wnioskowania na temat źródeł i kierunków transportu materiału w obszarze między Piotrkowem Trybunalskim, Radomskiem a Przedborzem (środkowa Polska). Acta Geographica Lodziensis 103: 57-77.

Kondracki J., 2000. Geografia regionalna Polski. Wyd. Nauk. PWN, Warszawa.

Kucharska M., Pochocka-Szwarc K., 2012. Objaśnienia do SMGP, ark. Wyszków (451). PIG PIB, Warszawa.

Lipka E., 2012. Zróżnicowanie cech petrograficznych osadów polodowcowych na Wysoczyźnie Lubuskiej. Praca doktorska. Arch. Instytutu Geoekologii i Geoinformacji UAM, Poznań.

Lüttig G., 1958. Methodische Fragen der Geschiebeforschung. Geologisches Jahrbuch 75: 361-418. 
Marks L., Karabanov A., Nitychoruk J., Bahdasarau M., Krzywicki T., Majecka A., Pochocka-Szwarc K., Rychel J., Woronko B., Zbucki Ł., Hradunova A., Hrychanik M., Mamchyk S., Rylova T., Nowacki Ł., Pielach M., 2016. Revised limit of the Saalian ice sheet in central Europe. Quaternary International DOI: 10.1016/j.quaint.2016.07.043: 1-16.

Meyer K.-D., 1983. Indicator pebble and stone count methods. W: J. Ehlers (red.), Glacial deposits in North-West Europe. Balkema, Rotterdam: 275-287.

Meyer K.-D., 1985. Zur Methodik und über den Wert von Geschiebezählungen. Der Geschiebesammler 19(2/3): 75-83.

Nowak J., 1969. Objaśnienia do Szczegółowej mapy geologicznej Polski, arkusz Serock (N34-127A). Wydawnictwa Geologiczne, Warszawa.

Rutkowski J., 1995. Badania petrograficzne żwirów. W: E. Mycielska-Dowgiałło, J. Rutkowski (red.), Badania osadów czwarto- rzędowych. Wybrane metody i interpretacja wyników. Uniwersytet Warszawski, Państwowy Instytut Geologiczny, Komitet Badań Czwartorzędu PAN, Warszawa: 133-150.

Schulz W., 1996. Zur Bedeutung der Korngröße bei Geschiebezählungen. Der Geschiebesammler 29(3): 91-102.

Trembaczowski J., 1961. Przyczynki do metodyki badań granulometryczno-petrograficznych utworów morenowych. Annales Universitatis M. Curie-Skłodowska, sec. B 16(3): 63-95.

Trembaczowski J., 1967. Granulometryczno-petrograficzna charakterystyka glin zwałowych Wysoczyzny Konińskiej. Prace Instytutu Geologicznego 48: 147-162.

Zabielski R., 2006. Badania litologiczno-petrograficzne osadów plejstoceńskich. SMGP w skali 1:50 000, ark. Wyszków. PIG PIB, Warszawa. 